\title{
DRD2 wt Allele
}

National Cancer Institute

\section{Source}

National Cancer Institute. DRD2 wt Allele. NCI Thesaurus. Code C51440.

Human DRD2 wild-type allele is located within $11 \mathrm{q} 23$ and is approximately $66 \mathrm{~kb}$ in length. This allele, which encodes $\mathrm{D}(2)$ dopamine receptor protein, plays a role in the inhibition of adenylyl cyclase activity. A missense mutation in this gene causes myoclonus dystonia and allelic variant mutants are associated with schizophrenia. 